\title{
Vergi Uyuşmazlıklarının İdari ve Adli Yargı Kapsamında Çözüm Süreçleri ve Önerileri
}

\section{The Solution Process and Suggestions of Tax Disputes within the Scope of Administrative and Judicial Jurisdiction}

\author{
Baki Yegen ${ }^{\text {a,* }}$

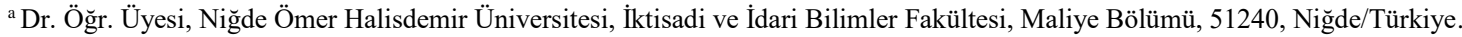 \\ ORCID: 0000-0003-4118-1445
}

\section{MAKALE BILGİSI}

\section{Makale Geçmişi:}

Başvuru tarihi: 27 Eylül 2018

Düzeltme tarihi: 27 Ağustos 2018

Kabul tarihi: 30 Ekim 2018

Anahtar Kelimeler:

Vergi uyuşmazlıkları

İdari Yarg1

Adli Yarg1

\section{ARTICLE INFO}

\section{Article history:}

Received 27 September 2018

Received in revised 27 August 2018

Accepted 30 October 2018

\section{Keywords:}

Tax Disputes

Administrative Judiciary

Judicial Judiciary

\section{ÖZ}

Vergi alacaklısı olan devlet ile borçlu konumunda olan birey arasında vergileme ilişkisi ile ilgili olarak zaman zaman anlaşmazlıklar yaşanmaktadır. Söz konusu anlaşmazlıklar literatürde vergi uyuşmazlığı olarak ifade edilmektedir. Vergi uyuşmazlıkları idare tarafından hesaplanan ödenecek vergi miktarı konusunda olabileceği gibi mükelleflerin vergi kanunlarına aykırı hareket etmeleri neticesinde aldıkları cezalar konusunda da olabilmektedir. Cezalar eylem türlerine göre idare tarafından ya da adli merci tarafından verilmektedir. Verilen cezalarla ilgili yaşanan uyuşmazlıklarda mükelleflere kanun yollarına gidebilme hakkı tanınmaktadır. Bu kapsamda mükelleflerin takip edebilecekleri kanun yolları benzerlik göstermesine rağmen yargı organları ve çözüm süreçleri farklılık göstermektedir.

\section{A B S T R ACT}

About the taxation relationship disputes are experienced from time to time between tax creditor state with the debtor individual. The dispute is referred as tax disputes in the literature. Tax disputes may be about the amount of payable tax which is calculated by the administration or may be about the penalties which are as a result of taxpayers act contrary to the laws of tax. Penalties is given according to the type of action by the administration or by the judicial authority. The taxpayers are entitled applying to legal means about the disputes which are including the penalties. In this context, although taxpayers can follow the similar ways, judicial bodies and the solution processes can vary.

\section{Giriş}

Bilindiği üzere vergilendirme süreci birbirlerine taraf olan vergi idaresi ve mükellefler arasında yaşanmaktadır. Bu süreç kapsamında mükellefler ile idare arasında fikir ayrılıkları yaşanabilmektedir. Mükellefler vergilendirme işlemi esnasında oluşan hatalarla ilgili idare ile uyuşmazlık yaşayabilecekleri gibi vergilendirme işlemi sonunda Vergi Usul Hukukunda yer alan eylemleri neticesinde alacakları cezalar konusunda da idare veya adli yargı mercileri ile uyuşmazlık yaşayabilmektedirler. Mükellefler ile vergi idaresi arasında yaşanan vergi uyuşmazlıklarına konu olan cezalar maddi nitelikli yani para cezaları iken, mükellefler ile adli yargı mercileri arasında yaşanan vergi uyuşmazlıklarına konu olan cezalar hürriyeti bağlayıcı nitelikli yani hapis cezaları olarak karşımıza çıkmaktadır. Hukuk sistemimizde kişilere hatalı olarak verildiği ileri sürülen yarg1 kararlarının, yeniden incelenmeleri ve değiştirilmeleri olanağı sağlayan kanun yollarına gidebilme hakkı tanınmaktadır. Yani mükellefler vergi ile ilgili olarak gerek idari yarg1, gerekse adli yargı makamları tarafindan verilen ceza kararlarına karşı kanun yollarına gidebilmektedir. Ancak adli çözüm süreçleri ile idari çözüm süreçleri birbirlerinden farklı olmaktadır. Bu noktadan hareketle çalışmada iki farklı çözüm süreci incelenerek süreçlerin benzeyen ve farklılık gösteren yönleri üzerinde durulacaktır.

*Sorumlu yazar/Corresponding author.

e-posta: bakiyegen@ohu.edu.tr 


\subsection{Vergi Uyuşmazlığı Kavramı}

Genel anlamda uyuşmazlık, karşılıklı olan iki tarafın bir konu üzerinde değişik görüşlere sahip olmaları nedeniyle ortaya çıkan anlaşmazlık şeklinde tanımlanmaktadır (Kızılot ve Kızılot, 2010: 51). Uyuşmazlık bireyler arasında cereyan edebileceği gibi bireyler ile idare arasında da cereyan edebilmektedir. Toplu yaşamanın gereği olarak taraflar arasında pek çok konuda uyuşmazlık yaşandığ bilinmektedir. Uyuşmazlık yaşanan konulardan birisi de vergi konusudur (Karakoç, 2013: 4). Vergi uyuşmazlığı, vergi idaresi ile mükellef, vergi sorumlusu, iştirakçi veya ceza muhatabı gibi taraflar arasında vergilendirme ilişkisine bağlı olarak ortaya çıkan anlaşmazlıklardır. Vergi uyuşmazlıkları, genel olarak vergi mevzuatının gereğince uygulanmaması ya da yanlış bir şekilde uygulanması, vergiyi doğuran olay, mükellefiyet, tarh, tebliğ, tahakkuk, tahsil ve ceza uygulanması esnasında taraflar arasında yaşanan anlaşmazlıkları kapsamaktadır (Yüce, 2014: 53).

\section{Vergi Uyuşmazlıklarının Çözüm Yolları}

Vergi uyuşmazlıklarında çözüm yolu, vergi yükümlüsü ya da vergi idaresinin uyuşmazlığı ortadan kaldırmaya yönelik hukuki araçlardan yararlanarak hukuk zemininde anlaşmaları veya her iki tarafın sonucuna uymak zorunda oldukları yargı mercilerinin kararı ile anlaşmazlığı sona erdirme yöntemleridir (Bayrakl1, 2009: 101).

Türk hukukunda bireyler ile devlet arasında meydana gelen vergi uyuşmazlıklarının çözümünü sağlamak üzere farklı yöntemlerin benimsendiği görülmektedir. Söz konusu yöntemler idari diğer ismiyle barışçıl çözüm yöntemlerinden ve yargısal çözüm yönteminden oluşmaktadır.

\subsection{Vergi Uyuşmazlıklarının İdari (Barışçı1) Çözüm Yolları}

Devlet ile mükellef arasındaki çıkar dengesini kurmayı amaçlayan vergi hukukunda vergilemeye ilişkin olarak ortaya çıkan uyuşmazlıkları verginin tarafları olan mükellef, sorumlu, ceza muhatabı ile vergi idaresi arasında barışçıl yollarla çözümü büyük önem taşımaktadır (Yüce, 2014: 54). Çünkü tüm vergi uyuşmazlıklarının vergi yargı organlarına intikal ettirilmesi durumunda en mükemmel yarg1 sistemi bile aksamaya başlayacaktır. Etkin bir vergi yargı sisteminin oluşabilmesi için vergi yarg1 organları ve görevlilerin bağımsız olması, vergi yargı sisteminin hızlı çalışmasının yanı sıra idari çözüm yolunun geliştirilmesi ve vergilemenin diğer unsurlarında etkinliğin sağlanmış olması gerekmektedir (Savaşan vd., 2012: 128).

Ülkemizde idari çözüm yolları esas olarak uzlaşma ve hata düzeltme kurumları olmak üzere cezalarda indirim ile pişmanlık ve ıslah kurumlarından oluşmaktadır. Kuşkusuz uyuşmazlıkların çözümlerinde barışçıl yöntemlerin kullanılmaları daha fazla arzu edilmektedir. Çünkü barışçıl

1 Diğer bir ifadeyle uyuşmazlık yaşayarak arabulucuya başvurulan durumlarda yöntemin \%97 oranında başarılı sonuç elde ettiği görülmektedir. Öte yandan dava açmak için ön şart olarak arabuluculuk müessesine başvurulan dosyalara ait istatistiklere göre yapılan görüşmelerin \%65'inde taraflar arasında anlaşma sağlandığı da görülmektedir. ${ }^{2}$ Başarı yüzdesinin bu kadar yüksek olduğu bir uyuşmazlık çözüm yönteminin vergi hukuku alanında da uygulanmasının tahsil yöntemler uyuşmazlıkların hem kısa sürede çözülmelerini hem çözüm için harcanan bedellerin en az seviyede gerçekleşmesini, hem de yargının iş yükünün azalmasını sağlamaktadır.

Taraflar arasında yaşanan uyuşmazlıkların çözümü için dünya genelinde yaygın olarak kullanılan alternatif çözüm yöntemlerinden birisi de arabuluculuktur. Arabuluculuk, tarafsız bir üçüncü kişinin taraflar arasındaki iletişimi, müzakereyi kolaylaştırdığı ve tarafların özel hukuk alanındaki uyuşmazlıkları konusunda kendi rızaları ile karar vermelerini sağlayan çözüm yöntemi olarak tanımlanmaktadır. $\mathrm{Bu}$ yöntem ile uyuşmazlıkların mahkemeye yansımadan taraflar arasında anlaşma sağlanarak basit ve kısa zamanda çözümlenmesi amaçlanmaktadır. Arabuluculuk yöntemi Anglo Sakson kaynaklı bir yapıya sahip olmasından ötürü öncelikli olarak Amerikan ve İngiliz hukuk sistemlerinde yer almış, zamanla söz konusu yöntem başta Avrupa ülkeleri olmak üzere tüm dünyada uygulanma alanı bulmaya başlamıştır (Bilgin, 2009: 16-17). Ülkemizde de yakın zamanda arabuluculuk yöntemine ilişkin faaliyetlerde bulunulduğu görülmektedir. $\mathrm{Bu}$ anlamda ülkemizde yaşanan ilk somut gelişme 7.6.2012 tarihinde 6325 sayılı Hukuk Uyuşmazlıklarında Arabuluculuk Kanunu'nun kabul edilmiş olmasıdır. Söz konusu kanuna ilişkin olarak Adalet Bakanlığı tarafindan çıkarılan ilk yönetmelik 26.01.2013 tarihinde 28540 sayılı Resmi Gazete'de yayımlanmış, ardından 2013 yılının Mart ayında ise Arabuluculuk Daire Başkanlığı tarafindan "Türkiye Arabuluculuk Kurulu Arabuluculuk Sistemi Ve Arabulucular İçin Model Etik Ve Uygulama Kuralları" belirlenmiştir. Ayrıca 25.10.2017 tarihinde 30221 sayılı Resmi Gazete'de yayımlanan 7036 sayılı İş Mahkemeleri Kanunu ile 5521 sayılı İş Mahkemeleri Kanunu yürürlükten kaldırılmış ve 7036 sayılı kanunun 3 üncü maddesi kapsamında işçi ile işveren arasında yaşanan uyuşmazlıklarda bazı durumlarda dava açmadan önce arabuluculuk müessesesine başvuru zorunluluğu getirilmiştir. Arabuluculuk konusunda yaşanan en güncel gelişme ise 02 Haziran 2018 tarihinde 30439 sayılı Resmi Gazete'de yayımlanan yönetmeliğin yürürlüğe girmesidir. Böylece 2018 yılında yayımlanan yönetmelik ile 2013 yılında yayımlanmış olan yönetmelik yürürlükten kaldırılmıştır.

Arabuluculuk yöntemi her ne kadar Türk Hukuk Sistemine yakın zamanda girerek kendine yer edinmiş olsa da söz konusu yöntemin sadece özel hukuk uyuşmazlıklarında kullanılabilen bir yöntem olması nedeniyle kamu hukuku dallarından birisi olan vergi hukukunda uygulama alanı bulamaması hususu dikkat çekmektedir. Oysaki arabuluculuk yönteminin ülkemizde uygulanmaya başlandığı günden beri 16 farklı konuda toplam 15.655 adet özel hukuk uyuşmazlığının sadece 421 tanesinde anlaşma sağlanamadığı, geri kalan 15.234 uyuşmazlığın anlaşma sağlanarak çözüme kavuşturulduğu görülmektedir.

edilecek vergi miktarı üzerinde oldukça olumlu bir etki meydana getireceği ise kolaylıkla tahmin edilebilmektedir.

\subsection{Vergi Uyuşmazlıklarının Yargısal Çözüm Yolları}

Vergi uyuşmazlıklarının idari çözüm yolları neticesinde çözülemediği durumlarda dava açma yoluna gidilmek 
suretiyle yargısal çözüm yöntemi kullanılabilmektedir. Yani söz konusu uyuşmazlık yargı alanına taşınmaktadır (Taşkan, 2007: 33). Vergi uyuşmazlıklarının dava yolu ile çözümlenmesinde ülkeden ülkeye farklı uygulamalar görülebilmektedir. Bazı ülkelerde adli yargıya bağlı, bazı ülkelerde idari yargı bünyesinde, çok az olmakla birlikte her ikisinin karma şekilde kullanıldığı yarg1 sistemlerine rastlanılmaktadır. Ülkemizde, idari yargıya bağlı vergi yargısı sistemi benimsenmiştir (Kızılot vd., 2006: 267).

Fakat bazı durumlarda vergi uyuşmazlıklarında yargısal çözüm yolu olan dava açma yolu uyuşmazlığa konu olan unsurun çeşidine göre farklı mercilerde görülmektedir. Şöyle ki genel olarak vergi uyuşmazlığına neden olan unsur neticesinde idari yargı mahkemelerine dava açılabileceği gibi hürriyeti bağlayıcı cezaların hükmolunduğu bazı durumlarda adli yargı mahkemelerine dava açılabilmektedir. Ayrıca ülkemizde bazı özellikli durumlarda doğrudan Anayasa Mahkemesi'ne ve Danıştay'a dava açılabileceği gibi bazı vergi davaları da Uyuşmazlık Mahkemesinin görev alanına girmektedir. Bu bağlamda çalışmada ilk olarak idari yargı mahkemelerine açılan davalara, sonra adli yargı mahkemelerine açılan davalara, daha sonra ise yüksek mahkemelerde görülen özellikli davalara değinilecektir.

\subsection{1. İdari Yarg1 Mahkemeleri Kapsaminda Uyuşmazlık Çözümü}

Ülkemizde vergi uyuşmazlıkları genel olarak idari yargının görev alanına girmektedir. Vergi, resim ve harçların tarh, tebliğ, tahakkuk, tahsil işlemleri ile ilgili veya kesilen cezalardan kaynaklanan vergi uyuşmazlıklarının, ülkemizdeki yargı yolu ile çözümü; vergi mahkemeleri ${ }^{3}$, bölge idare mahkemeleri ${ }^{4}$ ile Danıştay ${ }^{5}$ tarafindan gerçekleştirilmektedir (Akdoğan, 2006: 148). Bu bağlamda vergi uyuşmazlıklarını çözmekle görevli genel ve ilk derece mahkemesi olarak vergi mahkemeleri belirlenmiştir. Vergi mahkemelerinde davalara dava konusu olan tutara göre tek hâkimle ya da bir başkan ve iki üyeden oluşan kurul (heyet) halinde bakılmaktadır. ${ }^{6}$

Vergi mahkemelerinde görülen davalar sonucunda verilen kararlar bazı durumlarda kesin nitelik taşımakla birlikte bazı durumlarda tekrar incelenmeleri amaciyla üst mahkemelere gönderilmektedir. Şöyle ki vergi mahkemesi tarafindan verilen bir karar gerekli parasal sınır koşulunu sağlamadığı takdirde kesin karara dönüşmekteyken, parasal sınır koşulunu sağladığı takdirde istinaf yolu ${ }^{7}$ ile bölge idare mahkemesinde incelenebilmektedir. Yine bölge idare mahkemesinde incelenen bir karar da parasal sınır koşulunu sağlamadığı takdirde kesin nitelikli bir karara dönüşebileceği gibi gerekli parasal sınır koşulunu sağlaması halinde temyiz yolu ile Danıştay'da incelenebilmektedir. Söz konusu parasal sınırlara ise 2577 sayılı İdari Yargılama Usulü Kanunu'nun (IYYUK) 45 inci ve 46 inc1 maddelerinde yer verilmektedir. ${ }^{8}$ Buna göre;

*5.000 TL ve altında kalan tutarlara ilişkin uyuşmazlıklarda;

- İlk derece mahkemesinde dava açılır ve verilen karar kesin nitelik taşır,

- Mahkeme tarafindan verilen karara karşı istinaf incelemesi başvurusunda bulunulamaz,

- Temyize başvurulamaz.

*5.000 ila 117.000 TL arasında olan uyuşmazlıklarda;
İlk derece mahkemesinde dava açılır,

Mahkeme tarafından verilen karara karşı istinaf incelemesi başvurusunda bulunulur ve verilen karar kesin nitelik taşır,

Temyize başvurulamaz.

*117.000 TL ve üzeri uyuşmazlıklarda;

- İlk derece mahkemesinde dava açılır,

- Mahkeme tarafından verilen karara karşı istinaf incelemesi başvurusunda bulunulur, İstinaf sonrası temyize başvurulabilir.

Özetle uyuşmazlığa konu tutarın 5.000 TL ve altında olması halinde anlaşmazlıkların çözümlerinde ilk derece mahkemeleri olan vergi mahkemelerinin kararları kesin nitelik taşımaktadır. Bu tutardan yüksek olan meblağlara konu olan uyuşmazlıklarda ise 117.000 TL sınırı belirlendiği görülmektedir. Buna göre 5.000 TL ila 117.000 TL arasındaki uyuşmazlıklarda vergi mahkemesi kararına karşı istinaf yoluna gidilebilmekte fakat temyize gidilememekte, $117.000 \mathrm{TL}$ ve üzerindeki uyuşmazlıklarda ise vergi mahkemesi kararına karşı önce istinaf yoluna gidilebilmekte daha sonra da temyiz yoluna gidilebilmektedir. Anlaşıldığ üzere vergi mahkemesi kararlarına karşı doğrudan temyiz yolu ile Danıştay'a başvurulamamaktadır. Çünkü vergi mahkemelerinin kararlarına karşı temyiz yoluna gidilmeden önce mahkemenin bulunduğu yerdeki veya yargı çevresindeki Bölge İdare Mahkemesi'ne istinaf başvurusunda bulunulması gerekmektedir.

Anlaşmazlığa konu olan tutar 5.000 TL'den fazla olduğu takdirde istinaf başvurusu vergi mahkemesinin bulunduğ yargı çevresindeki bölge idare mahkemesine hitaben yazılan dilekçeyle, kararın tebliğinden itibaren otuz gün içinde yapılmalıdır. İstinaf başvurusu neticesince Bölge İdare Mahkemesi ilk derece mahkemesinin kararını hukuka uygun bulduğu takdirde başvuruyu reddetmekte, hukuka uygun bulmadığ kaldırmakta ve yeniden karar vermektedir. Bölge idare mahkemelerinin temyize açık olmayan kararları kesin olmaktadır. Bu kararlar, dosyayla birlikte kararı veren vergi mahkemesine gönderilir ve bu mahkemelerce yedi gün içinde tebliğe çıkarılır (İYUK, md. 45).

Temyize gidilebilecek durumlarda yani 117.000 TL ve üzeri tutarlardaki uyuşmazlıklarda istinaf yoluna gidilip istenilen sonuç alınamadığı takdirde temyize gidilebilmektedir. Buna göre bölge idare mahkemelerinde görülen ve konusu 117.000 Türk lirasını aşan vergi davaları Danıştay'da, kararın tebliğinden itibaren otuz gün içinde temyiz edilebilmektedir. Temyiz başvuruları Danıştay Başkanlığına hitaben yazılmış dilekçeler ile kararı veren bölge idare mahkemesine veya doğrudan Danıştay'a yapılmaktadır. Danıştay'ın ilgili dava dairesi (3,4,7 ve 9. daireler) Bölge İdare Mahkemesi tarafından verilen kararı hukuka uygun bulduğu takdirde kararı onamakta, kararın sonucu hukuka uygun olmakla birlikte gösterilen gerekçeyi doğru bulmaz veya eksik bulursa, kararı, gerekçesini değiştirerek onamaktadır. Ayrıca kararda yeniden yargılama yapılmasına ihtiyaç duyulmayan maddi hatalar ile düzeltilmesi mümkün eksiklik veya yanlışlıklar olması halinde kararı düzelterek onamaktadır. Danıştay temyiz incelemesi sonunda görev ve yetki dışında bir işe bakılmış olması, hukuka aykırı karar verilmesi ve usul hükümlerinin uygulanmasında kararı etkileyebilecek nitelikte hata veya eksikliklerin bulunması 
gerekçeleriyle kararı bozabilmektedir. Öte yandan Danıştay kararların kısmen onanması ve kısmen bozulması şeklinde de görüş bildirebilmektedir. Temyiz incelemesi sonucunda verilen karar onama yönünde ise hem vergi mahkemesine hem bölge idare mahkemesine gönderilmektedir. Verilen bozma yönünde bir karar ise sadece bölge idare mahkemesine gönderilmektedir. Bozma kararı sonrasında bölge idare mahkemesi dosyayı öncelikle incelemekte ve varsa gerekli tahkik işlemlerini tamamlayarak yeniden karar vermektedir. Bölge idare mahkemesi Danıştay'ın bozma kararına uyabileceği gibi kararında ısrar da edebilmektedir. Israr kararının temyizi hâlinde, talep, Danıştay Vergi Dava Daireleri Kurulunca incelenmekte ve karara bağlanmaktadır.

Vergi uyuşmazlıkları ile ilgili olarak yukarıda bahsedilen olağan kanun yolları tüketildikten sonra bireysel başvuru yoluyla Anayasa Mahkemesi'ne gidilebilmektedir (Korkmaz, 2015: 163-1964). Ülkemizde söz konusu yöntem 23 Eylül 2012 tarihinden itibaren uygulanmaya başlanmıştır (Erdoğdu, 2013: 102). Anayasa'nın 148. Maddesinin 3. fikrasına göre "Herkes, Anayasada güvence altına alınmış temel hak ve özgürlüklerinden, Avrupa İnsan Hakları Sözleşmesi kapsamındaki herhangi birinin kamu gücü tarafından, ihlal edildiği iddiasıyla Anayasa Mahkemesine başvurabilir. Başvuruda bulunabilmek için olağan kanun yollarının tüketilmiş olması şarttır." Vergi ödevi de Anayasa'daki temel hak ve özgürlükler kısmının siyasi hak ve ödevler bölümünde yer almış olduğu için vergi ödevi ile ilgili hususlarda vatandaşlara temel hak ve özgürlüklerinin ihlal edildikleri iddiasıyla olağan kanun yollarını tüketmiş olmak şartıyla bireysel başvuru hakkı tanınmaktadır. ${ }^{9}$

Öte yandan uyuşmazlık konusunda Anayasa Mahkemesi'ne bireysel başvuru yolunun tüketilmesi durumunda kişi bu defa Avrupa İnsan Hakları Sözleşmesinde düzenlenen hakların ihlal edildikleri gerekçesiyle Avrupa İnsan Hakları Mahkemesine (AİHM) başvuru yapabilmektedir (Ekinci ve Sağlam, 2012: 37-38). AİHM'ne başvuru yapabilmek için de iç hukuk yollarının tüketilmesi gerekmektedir. Kural olarak iç hukuk yollarının tüketilmesinden itibaren 6 ay içinde Avrupa İnsan Hakları Mahkemesi'ne başvuru yapılmalıdır. Vergi idaresi ile ilgili yaşanan uyuşmazlıklarda önce vergi mahkemesine, sonra istinaf yolu ile bölge idare mahkemesine, daha sonra temyiz yolu ile Danıştay'a ve son olarak Anayasa Mahkemesine bireysel başvuru yolu ile gidilmiş olması gerekmektedir. İstinaf ve temyiz yolu kapalı olan mahkeme kararlarına karşı ise Anayasa Mahkemesine bireysel başvuru yapılabilmektedir (Batı, 2015: 29). Anayasa Mahkemesi kararından da sonuç alınamaması halinde AİHM'ne başvuru yapılması gerekmektedir.

IYYUK md. 53/1-1'ya göre “Hükmün, İnsan Haklarını ve Ana Hürriyetleri Korumaya Dair Sözleşmenin veya eki protokollerin ihlâli suretiyle verildiğinin, Avrupa İnsan Hakları Mahkemesinin kesinleşmiş kararıyla tespit edilmiş olması veya hüküm aleyhine Avrupa İnsan Hakları Mahkemesine yapılan başvuru hakkında dostane çözüm yada tek taraflı deklarasyon sonucunda düşme kararı verilmesi." durumlarında Danıştay ile bölge idare, idare ve vergi mahkemelerinden verilen kararlar hakkında yargilamanın yenilenmesi istenebilmektedir. İlgili hükümden anlaşıldığı üzere AİHM'ne yaptığı başvuru neticesinde olumlu sonuç alan kişiler ülkemizde ilgili Türk mahkemesinden yargılamanın yenilenmesi isteyebilmektedir.
Ayrıca vergi mahkemelerinde, vergi uyuşmazlıklarından doğan davaların açılması, tarh edilen vergi, resim ve harçlar ile benzeri mali yükümlerin ve bunların zam ve cezalarının dava konusu edilen bölümünün tahsil işlemlerini durdurmaktadır (IYYUK md. 27/4). Yani idari yarg1 kapsamında görülen vergi davalarında davaya konu uyuşmazlıkla ilgili tahsilat işlemleri vergi mahkemelerinde görülürken yürütme kendiliğinden durmaktadır. Ancak Danıştay'da veya idari mahkemelerde dava açılması dava edilen idari işlemin yürütülmesini durdurmamaktadır (IYYUK md. 27/1). Danıştay'da ve idari mahkemelerde görülen vergi davalarında yani istinaf veya temyiz kanun yollarına gidildiğinde yürütme kendiliğinden durmamakta, yürütmenin durdurulması için kişilerin teminat karşılığında dava dosyasının incelenmekte olduğu yargı organına yani Danıştay'a veya bölge idare mahkemesine talepte bulunması gerekmektedir (İYUK md. 52/1).

\subsubsection{Adli Yarg1 Mahkemeleri Kapsamında Uyuşmazlık Çözümü}

Vergisel uyuşmazlıkların çözümünde görev alan yarg1 yerleri, farklı durumlara göre vergi mahkemesi, bölge idare mahkemesi, Danıştay ve bazı ceza uygulamaları yönünden ceza mahkemeleri olmaktadır (Taşkan, 2007: 122).

Vergi uyuşmazlığına konu olan unsurlar arasında vergi yükümlüsü ya da vergi sorumlusunun vergisel ödevleri zamanında ve hukuka uygun olarak yerine getirmediği durumlarda yer almaktadır (Bayraklı, 2009: 7). Bu gibi durumlar karşısında ise kişilere cezalar uygulanmaktadır. Söz konusu cezalar vergi uyuşmazlığına yol açan eylemlerin türlerine göre çeşitlilik gösterdikleri için cezalar eylemin türüne göre vergi idaresi ya da adli yargı tarafindan verilmektedir.

İdari makamlarca kesilen vergi cezaları 213 sayılı Vergi Usul Kanunu'nun (VUK) 331. maddesinde belirtildiği üzere vergi ziya1, usulsüzlük ve özel usulsüzlük kabahatlerine kesilen cezalardır. İdari cezalar, bireylerin ve toplulukların idari düzene aykırı davranışları nedeniyle idarece tertip edilen cezalardır. Anayasa'nın 38. maddesinin 10. fikrasına göre, idare, kişi hürriyetinin kısıtlanması sonucunu doğuran bir müeyyide uygulayamaz. $\mathrm{Bu}$ nedenle idare tarafindan verilen cezaların suçların niteliğine göre değişen parasal tutarlardan oluştukları yani mali nitelikli cezalar oldukları görülmektedir. Görüldüğü üzere suçların cezalandırılmasında idare bir bakıma hem taraf hem de yargıç işlevi görmektedir (Altundiş, 2007: 170). Söz konusu cezalara karşı ise idari yarg1 yollarına başvurulabileceğine ilişkin açıklamalara yukarıda yer verilmiştir.

VUK'ta düzenlenen ve vergi uyuşmazlığına yol açan eylemlerden kimisi sadece vergi hukukunu ilgilendirmekte ve bunların eylem ve yaptırımları idarî yöntemler ile belirlenmekte iken, kimisi ceza hukuku anlamında suç niteliğinde olarak değerlendirildiği için bunların eylemleri idari yöntemler ile VUK'ta belirlenmiş olmasına rağmen yaptırımları adli yöntemler ile belirlenmiştir (Ağar, 2005: 275). VUK'ta düzenlenmesine rağmen yaptırımlarının adli yöntemler ile belirlenmiş olduğu eylemler ise kaçakçılık, vergi mahremiyetini ihlal ve mükelleflerin özel işlerini yapma eylemleridir. Söz konusu eylemlerin içeriklerine, VUK'ta yer aldıkları kanun numaralarına ve eylemler neticesinde uygulanacak cezalara Tablo 1'de yer verilmiștir. 
Tablo 1. VUK'da Hürriyeti Bağlayıcı Cezalara Neden Olan Eylemler ve Cezaları

\begin{tabular}{|c|c|c|}
\hline $\begin{array}{l}\text { VUK } \\
\text { Madde }\end{array}$ & Suç Teşkil Eden Eylem & Cezası \\
\hline $359 / a$ & $\begin{array}{l}\text { *Defter ve kayıtlarda hesap ve } \\
\text { muhasebe hileleri yapmak } \\
\text { *Gerçek olmayan veya kayda } \\
\text { konu işlemlerle ilgisi } \\
\text { bulunmayan kişiler adına hesap } \\
\text { açmak } \\
\text { *Çift defter tutmak } \\
\text { *Defter, kayıt ve belgeleri tahrif } \\
\text { etmek veya gizlemek } \\
\text { *Muhteviyatı itibariyle yanıltıcı } \\
\text { belge düzenlemek veya bu } \\
\text { belgeleri kullanmak }\end{array}$ & $\begin{array}{l}\text { On sekiz aydan üç yıla } \\
\text { kadar hapis }+ \\
(3 \text { kat vergi ziyaı cezası) }\end{array}$ \\
\hline $359 / \mathrm{b}$ & $\begin{array}{l}\text { *Defter, kayit ve belgeleri yok } \\
\text { etmek } \\
\text { *Defter sahifelerini yok ederek } \\
\text { yerine başka yapraklar koymak } \\
\text { veya hiç yaprak koymamak } \\
\text { *Belgelerin asıl veya suretlerini } \\
\text { tamamen veya kısmen sahte } \\
\text { olarak düzenlemek veya bu } \\
\text { belgeleri kullanmak }\end{array}$ & $\begin{array}{l}\text { Üç yıldan beş yıla kadar } \\
\text { hapis }+ \\
\text { ( } 3 \text { kat vergi ziyaı cezası) }\end{array}$ \\
\hline $359 / \mathrm{c}$ & $\begin{array}{l}\text { * Maliye Bakanlığı ile } \\
\text { anlaşması bulunan kişilerin } \\
\text { basabileceği belgeleri, Bakanlık } \\
\text { ile anlaşması olmadığı halde } \\
\text { basmak veya bilerek kullanmak }\end{array}$ & $\begin{array}{l}\text { İki yıldan beş yıla kadar } \\
\text { hapis }\end{array}$ \\
\hline 362 & $\begin{array}{l}\text { *Vergi mahremiyetini ihlâl } \\
\text { etmek }\end{array}$ & $\begin{array}{l}\text { Bir yıldan üç yıla kadar } \\
\text { hapis ve beş bin güne } \\
\text { kadar adlî para cezası } \\
\text { (TCK 239. Md.) }\end{array}$ \\
\hline 363 & $\begin{array}{l}\text { * Mükelleflerin özel işlerini } \\
\text { yapmak }\end{array}$ & $\begin{array}{l}\text { Altı aydan iki yıla kadar } \\
\text { hapis cezası } \\
\text { (TCK 257. Md. 1. F1kra) } \\
\text { + Vergi ziyaına neden } \\
\text { olunması halinde, kişiye } \\
\text { ayrıca bu Kanunun } 344 \\
\text { üncü maddesine göre } \\
\text { vergi ziyaı cezası } \\
\text { kesilir. }\end{array}$ \\
\hline
\end{tabular}

Tablo 1'de görüldüğü üzere VUK'ta sadece mali nitelikli cezalar değil doğrudan veya Türk Ceza Kanunu'na (TCK) atıf yapılmak suretiyle bazı eylemler sonucunda hürriyeti bağlayıcı cezalar verileceği öngörülmektedir (Yurtyeri ve Yurtyeri, 2012: 106). Bu eylemler için söz konusu cezalar en az altı ay, en çok beş yıldır. Bu eylemler neticesinde verilen cezaların hürriyeti bağlayıcı olmaları yani hapis cezasını içermeleri nedeniyle idare tarafindan verilen mali nitelikli cezalardan ayrıldıkları görülmektedir. Yani bir tarafta para cezaları diğer tarafta ise hapis cezaları bulunmaktadır. Bu ise vergi uyuşmazlığına neden olan eylemler neticesinde uyuşmazlığın çözümü için gidilecek yargı yollarının farklılaşmasına yol açmaktadır. Nitekim idarece verilen cezalar ve bu cezalar neticesinde gidilecek yargı yolu ile adli makam tarafından verilen hürriyeti bağlayıcı nitelikteki cezalar ve bu cezalar neticesinde gidilecek yarg1 yolu birbirinden farklı olmaktadır.

Mali yaptırım gerektiren vergi suçlarının belirlenmesi ve cezalandırılması süreci doğrudan vergi idaresi bünyesinde gerçekleşmekte ve yaşanan uyuşmazlıklarda idari yargı yolları benimsenmesine rağmen adli yaptırım gerektiren vergi suçlarının VUK'ta belirlendiği, bu suçlara verilecek hürriyeti bağlayıcı nitelikteki cezaların ise bir kısmının
VUK'ta açıkça belirlendiği bir kısmının da yine VUK'ta TCK hükümlerine atıf yapılmak suretiyle belirlendiği için bu cezalar konusunda yaşanan uyuşmazlıklarda adli yargı yolları benimsenmektedir. Diğer bir ifade ile mali cezalarda kişilere cezayı idare verebilmekte iken, hürriyeti bağlayıcı cezalarda cezalar adli yargıda görevli asliye ceza mahkemeleri tarafindan verilmektedir. Nitekim 5235 sayllı Adlî Yargı İlk Derece Mahkemeleri ile Bölge Adliye Mahkemelerinin Kuruluş, Görev ve Yetkileri Hakkında Kanun'da ve 5271 sayılı Ceza Muhakemesi Kanunu'nda (CMK) bütün vergi suçları için tayin edilen görevli mahkeme asliye ceza mahkemeleri olarak karşımıza çıkmaktadır (Ömercioğlu vd., 2018: 55). Buna göre VUK'da hürriyeti bağlayıcı cezalara neden olan eylemler (Tablo 1) için kişilere verilecek ceza kararlarında ilgili merci asliye ceza mahkemeleri olmaktadır.

Hürriyeti bağlayıcı nitelikli vergi suçlarına verilen cezalarla ilgi süreç incelendiğinde vergi mahremiyetini ihlal suçunun düzenlendiği VUK'un 362. maddesinde bu suçla ilgili ceza konusunda TCK'nın 239. maddesine atıf yapılarak TCK'nın 239. madde hükümlerine göre ceza verileceği ifade edilmektedir. TCK'da 239. maddenin birinci fikrasında ise adı geçen kişilerin şikâyet üzerine cezalandırılacakları ifade edilmektedir. Hürriyeti bağlayıcı bir diğer vergi suçu olan mükellefin özel işlerini yapma suçu ile ilgili hükümler ise VUK'un 363. maddesinde düzenlenmektedir. VUK'un 363. maddesinde de ilgili suça verilecek ceza konusunda TCK'nın 257. maddesine atıf yapıldığ yapan memurlara TCK 257. madde hükümleri uygulanacağ 1 ifade edilmektedir. Ancak vergi mahremiyetini ihlal suçunda kişilerin şikâyet üzerine cezalandırılacakları açıkça TCK'nın 239. maddesinde belirtilmiş olmasın karşın, mükellefin özel işlerini yapma suçu ile ilgili yasal düzenlemelerin yer aldığ 1 TCK'nın 257. maddesinde kişilerin şikâyet üzerine cezalandırılacaklarına dair herhangi bir ifadeye yer verilmediği görülmektedir.

Hürriyeti bağlayıcı suçlardan kuşkusuz en önemlisi kaçakçılık suçudur. Bu bağlamda VUK'ta diğer hürriyeti bağlayıcı cezaların aksine kaçakçılık suçlarının cezalandırılma usulü 367. maddede düzenlenmiştir. Söz konusu kanun maddesine göre yaptıkları inceleme sırasında 359. maddede yazılı suçların işlendiğini tespit eden Vergi Müfettişleri ve Vergi Müfettiş Yardımcıları tarafından ilgili rapor değerlendirme komisyonunun mütalaasılyla doğrudan doğruya ve vergi incelemesine yetkili olan diğer memurlar tarafindan ilgili rapor değerlendirme komisyonunun mütalaasıyla vergi dairesi başkanlığı veya defterdarlık tarafindan keyfiyetin Cumhuriyet başsavcıllı̆̆ına bildirilmesi mecburidir. Yani kaçakçılık eyleminin inceleme elemanları tarafından tespit edildiği durumlarda söz konusu inceleme elemanları bu eylemi Cumhuriyet başsavcılığına bildirilmek zorundadırlar. Tersi durumda Cumhuriyet savcılarının da kaçakçılık suçu işlendiğine dair bilgi sahibi olmaları halinde TCK'da yer alan suçlarda olduğu gibi doğrudan soruşturma yapma yetkileri bulunmadığı 367. maddede ifade edilmektedir. Yine 367. maddede kaçakçılık suçu işlendiğine dair bilgisi olan Cumhuriyet savcısının ilgili vergi dairesini haberdar ederek inceleme yapılmasinı talep etmesinden sonra inceleme neticesinin Cumhuriyet başsavcıllğına bildirilmesiyle kamu davasının açılacağı hüküm altına alınmıştır. 
Vergi uyuşmazlığı kapsamında değerlendirilen hürriyeti bağlayıcı ceza ile neticelendirilen suçlara ilişkin cezaların adli yargı kapsamında asliye ceza mahkemelerinde görüldüklerine yukarıda değinilmiştir. Bu suçlara ilişkin verilen cezalar konusunda asliye ceza mahkemesi kararlarının yargılanan kişi ya da kişilerce beğenilmediği, diğer bir şekilde ifade etmek gerekirse uyuşmazlığın yaşandığı durumlarda itiraz ${ }^{10}$, istinaf ve temyiz kanun yollarına gidilebileceği görülmektedir. Şöyle ki asliye ceza mahkemesi tarafından verilen ceza, hâkim kararı ile verildiği için CMK'nın 267. maddesine göre mahkeme kararlarına karşı itiraz yoluna gidilebilmektedir (Aydın, 2006: 64). İtiraz usulü ve inceleme mercileri ise CMK'nın 268. maddesinde düzenlenmektedir. Buna göre mahkeme kararından zarar gören ilgili kişi kararı veren mercie yani asliye ceza mahkemesine verilecek bir dilekçe veya tutanağa geçirilmek koşulu ile zabıt kâtibine beyanda bulunmak suretiyle kararı öğrendiği günden itibaren yedi (7) gün içerisinde itiraz başvurusu yapmak zorundadır. Ancak, kararına itiraz edilen hâkim veya mahkeme, itirazı yerinde görürse kararını düzeltir; yerinde görmezse en çok üç gün içinde, itirazı incelemeye yetkili olan mercie yani yarg1 çevresinde bulundukları ağır ceza mahkemesine göndermekle yükümlüdür. İtiraz hakkındaki kararın mümkün olan en kısa sürede verilmesi esastır. Üst merci kural olarak duruşma yapmaksızın karar vermekte, itiraz haklı görüldüğü takdirde ise itiraz konusu kararı kaldırmaktadır. Ayrıca merciin, itiraz üzerine verdiği kararları kesin nitelik taşımaktadır (Şenyüz, 2015: 548).

İlk derece mahkemelerinden verilen hükümlere karşı istinaf yoluna da başvurulabileceği CMK'nın 272. maddesinde hükme bağlanmaktadır. ${ }^{11} \mathrm{Bu}$ durumda ilk derece mahkemelerinden olan asliye ceza mahkemelerinin de vergi suçlarına ilişkin verdikleri hükümlere karşı istinaf yoluna gidilebileceği açık bir şekilde görülmektedir. Ülkemizde istinaf istemini karara bağlayacak mahkemeler adli yargı ikinci derece mahkemeleri olan Bölge Adliye Mahkemeleri ${ }^{12}$ (BAM) olarak yapılandırılmışlardır. İstinaf istemi, hükmün açıklanmasından itibaren yedi (7) gün içinde hükmü veren mahkemeye başvuru yapılmak suretiyle gerçekleşmektedir. ${ }^{13}$ Süresi içerisinde yapılan istinaf başvurusu CMK'nın 275. maddesine göre hükmün kesinleşmesini engellemektedir. İstinaf başvurusu kabul edildiği takdirde dava dosyası bölge adliye mahkemesine sunulmak üzere gönderilmektedir. Dava dosyası, bölge adliye mahkemesine geldiğinde işbölümüne göre görevli ceza dairesine verilmektedir. Dava üzerinde ön inceleme yapılmakta sonra esas incelemeye geçilmektedir. İnceleme sonucunda (CMK md. 280/1);

a) Asliye ceza mahkemesinin kararının yerinde olduğunun tespiti halinde istinaf başvurusunun esastan reddine, 303 üncü maddenin birinci fikrasının (a), (c), (d), (e), (f), (g) ve (h) bentlerinde yer alan ihlallerin varlığı hâlinde hukuka aykırılığın düzeltilerek istinaf başvurusunun esastan reddine,

b) Cumhuriyet savcısının istinaf yoluna başvurma nedenine uygun olarak mahkûmiyete konu suç için kanunda yazılı cezanın en alt derecesinin uygulanmasını uygun görmesi hâlinde, hukuka aykırılığın düzeltilerek istinaf başvurusunun esastan reddine, c) Olayın daha fazla araştırılmasına ihtiyaç duyulmadan davanın reddine karar verilmesi veya güvenlik tedbirlerine ilişkin hatalı kararın düzeltilmesi gereken hâllerde hukuka aykırılığın düzeltilerek istinaf başvurusunun esastan reddine,

d) İlk derece mahkemesinin kararında 289 uncu maddenin birinci fikrasının (g) ve (h) bentleri hariç diğer bentlerinde belirtilen bir hukuka aykırılık nedeninin bulunması hâlinde hükmün bozulmasına ve dosyanın yeniden incelenmek ve hükmolunmak üzere hükmü bozulan ilk derece mahkemesine veya kendi yarg1 çevresinde uygun göreceği diğer bir ilk derece mahkemesine gönderilmesine,

e) Diğer hâllerde, gerekli tedbirleri aldıktan sonra davanın yeniden görülmesine ve duruşma hazırlığı işlemlerine başlanmasına, karar verir.

Duruşma sonunda bölge adliye mahkemesi istinaf başvurusunu esastan reddeder veya ilk derece mahkemesi hükmünü kaldırarak yeniden hüküm kurar (CMK md. 280/2).

Hürriyeti bağlayıcı ceza ile neticelendirilen vergi suçlarında yaşanan uyuşmazlıklarla ilgili gidilebilecek kanun yollarından birisi de temyizdir. Temyiz müessesesi CMK 286-307. maddelerinde düzenlenmektedir. Bölge adliye mahkemesi ceza dairelerinin bozma dışında kalan hükümleri temyiz edilebilmektedir. Ancak CMK md. 286/2'ye göre;

a) İlk derece mahkemelerinden verilen beş yıl veya daha az hapis cezaları ile miktarı ne olursa olsun adlî para cezalarına karşı istinaf başvurusunun esastan reddine dair bölge adliye mahkemesi kararları,

b) İlk derece mahkemelerinden verilen beş yıl veya daha az hapis cezalarını artırmayan bölge adliye mahkemesi kararları,

c) Hapis cezasından çevrilen seçenek yaptırımlara ilişkin ilk derece mahkemesi kararları ile ilgili olarak bölge adliye mahkemesince verilen; seçenek yaptırımlara ilişkin her türlü kararlar ve istinaf başvurusunun esastan reddine dair kararlar,

d) İlk derece mahkemelerinin görevine giren ve kanunda üst sınırı iki yıla kadar (iki yıl dâhil) hapis cezasını gerektiren suçlar ve bunlara bağlı adli para cezalarına ilişkin her türlü bölge adliye mahkemesi kararları,

e) Adlî para cezasını gerektiren suçlarda ilk derece mahkemelerinden verilen hükümlere ilişkin her türlü bölge adliye mahkemesi kararları,

f) Sadece eşya veya kazanç müsaderesine veya bunlara yer olmadığına ilişkin ilk derece mahkemesi kararları ile ilgili olarak istinaf başvurusunun esastan reddine dair kararlar1,

g) On yıl veya daha az hapis cezasını veya adlî para cezasını gerektiren suçlardan, ilk derece mahkemesince verilen beraat kararları ile ilgili olarak istinaf başvurusunun esastan reddine dair kararları,

h) Davanın düşmesine, ceza verilmesine yer olmadığına, güvenlik tedbirine ilişkin ilk derece mahkemesi kararları ile ilgili olarak bölge adliye 
mahkemesince verilen bu tür kararlar veya istinaf başvurusunun esastan reddine dair kararlar,

i) Yukarıdaki bentlerde yer alan sınırlar içinde kalmak koşuluyla aynı hükümde, cezalardan ve kararlardan birden fazlasını içeren bölge adliye mahkemesi kararları, temyiz edilemez.

Vergi suçlarına ilişkin verilen hürriyeti bağlayıcı cezalara karşı gidilebilecek kanun yollarından birisi temyiz olmasına rağmen CMK md. 286/2'de yer verilen hükümlerden anlaşıldığı üzere temyiz müessesine oldukça sınırlı şekilde gidilebilmektedir. Çünkü vergi suçlarına verilen hürriyeti bağlayıcı cezaların (Tablo 1) alt sınırının 6 ay, üst sınırının 5 yıl olduğu dikkate alındığında, vergi suçlarına verilecek adli cezalar konusunda yaşanacak uyuşmazlıkların çoğunlukla istinaf kanun yolu ${ }^{14}$ ile çözümlenebileceği, temyiz yolu ile Yargitay'a ise kanunda belirtilen sinırlı durumlar haricinde gidilemeyeceği sonucuna varılmaktadır (Öz ve Armağan, 2018: 18). Örneğin işlenmiş bir vergi kaçakçılığı suçuna ilişkin asliye ceza mahkemesi tarafindan verilen ceza (en fazla 5 yıl) ile ilgili uyuşmazlık yaşanıp istinaf yoluna gidilmesi halinde bölge adliye mahkemesinin vereceği karar kesin nitelik taşımakta olup temyiz yolu ile Yargıtay’a gidilememektedir. Ancak aynı suça ilişkin asliye ceza mahkemesinin vermiş olduğu cezanın bölge adliye mahkemesinde artırılması halinde temyiz yolu ile Yargıtay’a başvuru yapılması mümkün olmaktadır.

CMK'nın 288. maddesinde temyiz nedeni olarak hukuka aykırı bir durumun olması gerektiği ifade edilmekte, bir hukuk kuralının uygulanmaması veya yanlış uygulanması ise söz konusu maddede hukuka aykırılık olarak belirtilmektedir. Temyiz istemi, hükmün açıklanmasından itibaren on beş (15) gün içinde hükmü veren mahkemeye yani vergi suçlarında bölge adliye mahkemelerine başvurularak yapılmaktadır. CMK md. 293/1'e göre süresi içinde yapılan temyiz başvurusu, hükmün kesinleşmesini engellemektedir. Temyiz istemi, kanunî sürenin geçmesinden sonra yapılmış veya temyiz edilemeyecek bir hüküm temyiz edilmiş veya temyiz edenin buna hakkı yoksa hükmü temyiz olunan bölge adliye veya asliye ceza mahkemesi bir karar ile temyiz istemini reddetmektedir. Temyiz istemi kabul edildiğinde ise temyiz dilekçesinin bir örneği karşı tarafa tebliğ olunmakta ve tebliğ tarihinden itibaren yedi (7) gün içinde yazılı olarak karşı tarafın cevabı beklenmektedir. Cevap verildikten veya bunun için belirli süre bittikten sonra dava dosyası bölge adliye mahkemesi tarafindan Yargıtay Cumhuriyet Başsavcılığına gönderilmektedir. Yargitay Cumhuriyet Başsavcılı̆̆ için gelen dosyayı inceledikten sonra tebliğname ile birlikte vergi suçları ile ilgili ceza dairelerine ${ }^{15}$ teslim etmektedir. Dosyaya bakan ceza dairesi teslim alınan dosyayı ön incelemeye tabi tutmaktadır. Bu inceleme sırasında süresi içinde temyiz başvurusunda bulunulmadı̆̆ 1 , hükmün temyiz edilemez olduğu, temyiz edenin buna hakkı olmadığı ya da temyiz dilekçesinin temyiz sebeplerini içermediği saptandığ takdirde, temyiz istemi reddedilmektedir. Ön incelemeden geçen temyiz istemi esas incelemeye konu olup esas inceleme neticesinde ilgili ceza dairesinin vereceği karar belirleyici olmaktadır. Bölge adliye mahkemesinin temyiz olunan hükmünün Yargitay'ca hukuka uygun bulunması hâlinde temyiz isteminin esastan reddine, temyiz başvurusunda gösterilen hükmü etkileyecek nitelikteki hukuka aykırılıklar bulunması halinde hükmün bozulmasına karar verilmektedir. Ayrıca hükme esas olarak saptanan olaylara uygulanmasında hukuka aykırılıktan dolayı hüküm bozulmuş ise, CMK md. 303/1'de belirtilen durumların varlığı halinde Yargıtay davanın esasına hükmedebileceği gibi hükümdeki hukuka aykırılığı da düzeltebilmektedir. Temyiz istemi esastan reddedildiğinde, Yargıtay davanın esasına hükmettiğinde veya hükümdeki hukuka aykırılığg da düzelttiğinde dosya hükmü veren bölge adliye mahkemesine gönderilmesi için Yargıtay Cumhuriyet Başsavcılığına verilmekte, bölge adliye mahkemesi ise dosyay Yargitay'dan geldiği tarihten itibaren yedi gün içinde gereğinin yapılması için asliye ceza mahkemesine göndermektedir. Hükmün bozulmasına karar verilmesi durumunda ise Yargitay, dosyayı yeniden incelenmek ve hüküm verilmek üzere hükmü bozulan bölge adliye mahkemesine veya diğer bir bölge adliye mahkemesine göndermektedir. Bölge adliye mahkemesi Yargitay'ın bozma kararına uyup uymama konusunda serbesttir. Yani mahkeme bozma kararına uyabilmekte ya da direnebilmektedir. Mahkeme bozma kararına uyduğu takdirde bozma nedenlerini göz önünde bulundurarak yeni bir karar vermektedir. Mahkeme bozma kararına uymaz ise yani kendi vermiş olduğu karar hususunda direnirse bu kararın temyiz edilmesi durumunda inceleme, Yargitay Ceza Genel Kurulunca yapılmaktadır. Ve ceza genel kurulunun vermiş olduğu kararlar kesin hüküm niteliği taşımaktadır.

Ayrıca vergi uyuşmazlıklarının idari yargı kapsamında çözüm süreçleri ile ilgili yapılan açıklamalarda değinildiği üzere adli yarg1 alanında da vergi ile ilgili yaşanan uyuşmazlıklarda Anayasa'nın 148. maddesinin üçüncü fikrası uyarınca olağan kanun yolları tüketildikten sonra mülkiyetin korunması hakkının veya adil yargılanma hakkının ihlal edilmesi gerekçesiyle bireysel başvuru yoluyla Anayasa Mahkemesi'ne başvurmak mümkün olmakla birlikte Anayasa Mahkemesi'nden arzu edilen sonuç alınamaması halinde AİHM'ne başvuru yapilabilmektedir (Akdemir, 2014: 272).

\subsection{3. Özellikli Durumlar Kapsamında Yüksek Mahkemelerde Uyuşmazlık Çözümü}

Vergi uyuşmazlıklarının ülkemizde çözümü hususunda genel olarak adli ve idari yargı kapsamında yer alan ilk derece, ikinci derece ve üst derece mahkemeleri (yüksek mahkemeler) görevli olmaktadır. Ancak bazı özellikli durumlarda üst mahkemelere doğrudan dava açılabilmek mümkün olabildiği gibi farklı üst mahkemelerde de vergi ile ilgili davalar görülebilmektedir.

a) Şöyle ki 1982 Anayasası'nın 150, 151 ve 152. maddelerinde yer alan hükümler kapsamında vergiyle ilgili kanunların belirli madde ve hükümlerinin şekil ve esas bakımından Anayasaya aykırılığı iddiasıyla Anayasa Mahkemesinde doğrudan doğruya iptal davası açılabileceği gibi, davaya bakmakta olan mahkeme kanun hükümlerini Anayasaya aykırı gördügünde veya taraflardan birinin ileri sürdüğü aykırılık iddiasının ciddi olduğu kanısına vardığında da Anayasa Mahkemesinin bu konuda vereceği karara kadar davayı geri birakmaktadır. Yani Anayasa'da yer alan hükümler uyarınca vergi kanunlarının soyut norm (iptal davası) ve somut norm ${ }^{16}$ (itiraz yolu) denetimi mümkün olmaktadır. Bu 
durumda vergi uyuşmazlıklarında Anayasa Mahkemesi görevli olabilmektedir.

b) Ayrıca 2575 sayılı Danıştay Kanunu'nun 24/1-c maddesine göre "Bakanlıklar ile kamu kuruluşları veya kamu kurumu niteliğindeki meslek kuruluşlarınca çıkarılan ve ülke çapında uygulanacak düzenleyici işlemlere" karşı Danıştay ilk derece mahkemesi olarak davalara bakabilmektedir. Bu nedenle vergiyle ilgili düzenleyici işlemlere karşı ilgili kanun maddesi uyarınca Danıştay'da dava açmak mümkün olmaktadır.

c) Son olarak 1982 Anayasası'nın 158. maddesi gereğince adli ve idari yargı mercileri arasındaki görev ve hüküm uyuşmazlıklarını kesin olarak çözümlemeye Uyuşmazlık Mahkemesi yetkili kılınmıştır. Yani adli ve idari yargı organlarının birbirlerinin görev alanlarına müdahale etmeleri neticesinde ortaya çıkan vergi uyuşmazlıklarının çözümlerinde Uyuşmazlık Mahkemesi görevli olmaktadır. ${ }^{17}$

Vergi uyuşmazlıklarının çözümleri ile ilgili süreçler dikkate alındığında hem idari hem de adli yargı alanlarında öncelikle ilk derece mahkemeleri görevli olmakta, ilk derece mahkemelerinden sonuç alınamadığı ve belirli koşulların sağlandığ 1 durumlarda ikinci derece mahkemeler ve ardından üst mahkemeler görevli olmaktadır. Ancak vergi uyuşmazlıklarına ilişkin bazı durumlarda aynı üst mahkemeler doğrudan görevli olabildikleri gibi farklı üst mahkemeler kapsamında Anayasa Mahkemesi ve Uyuşmazlık Mahkemesi de görevli olabilmektedir. Anlaşıldığı üzere gerek adli gerek idari vergi uyuşmazlıklarının çözümlerinde her zaman ilk derece ve ikinci derece mahkemeler görevli olmayabilmektedir. Nitekim yukarıda ifade edilen durumların ilkinde doğrudan Anayasa Mahkemesi görevli merci olmakta, ikincisinde doğrudan Danıştay görevli merci olmakta, üçüncüsünde ise Uyuşmazlık Mahkemesi görevli merci olmaktadır.

\section{Sonuç ve Değerlendirme}

Vergi ilişkisi içinde bir yanda devlet diğer yanda bireyler olduğu sürece bir takım anlaşmazlıkların diğer bir ifade ile uyuşmazlıkların yaşanması kaçınılmaz görülmektedir. Söz konusu uyuşmazlıklar idari yargının görev alanına giren hususlarda olabileceği gibi adli yargının görev alanına giren hususlarda da yaşanabilmektedir. Şöyle ki kişiler ile vergi idaresi arasında vergilendirme ilişkisine bağlı olarak vergilendirme süreci, mevzuatın yanlış uygulanması ve kişilere kesilen idari para cezası gibi konularda anlaşmazlık ortaya çıkabilmektedir. Vergi idaresi ile uyuşmazlık yaşayan kişilerin uyuşmazlıkları ülkemizde uzlaşma, hata düzeltme, cezalarda indirim ile pişmanlık ve ıslah gibi barışçıl yollarla çözebilmeleri mümkün olmaktadır. Barışçıl yöntemler ile uyuşmazlık konuları yargı alanına taşınmadan kısa sürede ve en az maliyetle çözülebilmektedir. $\mathrm{Bu}$ nedenle barışçıl yolların daha çok tercih edilmelerini sağlayacak uygulamalara ağırlık verilmesi gerekmektedir. Söz konusu uygulamalardan bir tanesi de dünya genelinde uyuşmazlıkların çözümlerinde uygulanmakta olan arabuluculuk yöntemidir. Arabuluculuk yöntemi ülkemizde sadece özel hukuk alanındaki uyuşmazlıkların çözümlerinde kullanılmakta, dolayısıyla kamu hukuku ve vergi hukukunu kapsamamaktadır. Ancak arabuluculuk yönteminin ülkemizde yakaladığı yüksek başarı oranı dikkate alındığı zaman söz konusu yöntemin vergi hukukunda yaşanan uyuşmazlıkların çözümlerinde de etkin bir araç olacağı düşünülmektedir. Hatta özel hukukta uygulanan arabuluculuk yönteminin bazı uyuşmazlıklarda dava açmak için ön şart olarak belirlendiği durumların vergi hukuku alanı için de uyarlanması hem arabuluculuk yönteminin daha fazla kullanılmasına hem de bu yöntemle dava açılmasına gerek duyulmadan uyuşmazlıkların kısa sürede ve en az maliyetle çözülmelerine neden olacaktır.

Ülkemizde vergi uyuşmazlıkları barışçıl yollar ile çözülebileceği gibi idarenin her türlü eylem ve işlemlerine karşı yarg1 yolu (Anayasa md. 125) açık olduğu için uyuşmazlıkları yarg1 yolu ile de çözebilmektedir. Yani kişiler vergi idaresinin işlemlerine karşı dava açma hakkına sahiplerdir. Ancak kişiler idarenin yapmış olduğu eylemlere karşı açmış oldukları davalardan her zaman olumlu sonuç elde edememektedirler. $\mathrm{Bu}$ durumda kişiler idari yargı kararlarına karşı kanun yollarına başvurabilmektedir. Bazı durumlarda ise kişiler vergi ile ilgili gerçekleştirdikleri eylemler neticesinde adli yargının görev alanına giren konulara müdahil olarak hürriyeti bağlayıcı cezalar ile cezalandırılmaktadırlar. Adli yargı kapsamında kendisine hürriyeti bağlayıcı ceza verilen kişiler de verilen adli yargı kararlarına karşı kanun yollarına başvurabilmektedirler. Kısacası ülkemizde vergi davaları kapsamında gerek idari gerek adli yargı kararlarına karşı olağan ve olağanüstü kanun yolları açık bulunmaktadır.

İdari yargı kapsamındaki olağan kanun yollarının istinaf ve temyiz oldukları, adli yargı kapsamındaki olağan kanun yollarının ise itiraz, istinaf ve temyiz oldukları görülmüştür. İstinaf ve temyiz kanun yolları hem idari hem adli yargıda yer alan olağan kanun yolları olarak karşımıza çıkmaktadır. İki yargı kolunda da yer alan uygulamalar ile ilk derece mahkemelerinin vermiş oldukları kararların belirli şartları taşımaları halinde ikinci derece ve üst mahkemelerde incelenmelerine olanak sağlanmaktadır. Şöyle ki 2018 yılı için idari yargıda vergi uyuşmazlığına konu olan tutarın 5.000 TL ve altında bir değer olması halinde vergi mahkemesi kararının kesin olacağı ve olağan kanun yollarına gidilemeyeceği bilinmektedir. Uyuşmazlığa konu tutarın 5.000 TL ila 117.000 TL arasında olması halinde davanın istinaf yolu ile bölge idare mahkemelerinde incelenebileceği, uyuşmazlığa konu tutarın 117.000 TL ve üzerinde olması halinde ise davanın temyiz yolu ile Danıştay dava dairelerinde incelenebileceği bilinmektedir. İlgili Danıştay dava dairesinin (3.,4.,7. ve 9.) vereceği hükmün bozulması yönündeki karara karşı bölge idare mahkemesinin bozmaya uymayarak kararında ısrar etmesi halinde dava dosyası kararlarına uyulması zorunlu olan Danıştay Vergi Dava Daireleri Kurulunca incelenmekte ve karara bağlanmaktadır. Dolayısıyla vergiyle ilgili düzenleyici işlemlere karşı yukarıdaki mevzuat kapsamında Danıştay’da temyiz yolu ile dava açılabilir. Ayrıca 2575 sayılı Danıştay Kanunun 24/1-c maddesi gereğince "Bakanlıklar ile kamu kuruluşları veya kamu kurumu niteliğindeki meslek kuruluşlarınca çıkarılan ve ülke çapında uygulanacak düzenleyici işlemlere” karşı Danıştay'da ilk derece mahkemesi olarak dava da açılabilmektedir. Ancak adli yargıda asliye ceza mahkemeleri tarafindan verilen kararlar (CMK md. 267) itiraz yolu ile ağır ceza mahkemelerinde, yine asliye ceza mahkemeleri tarafindan verilen kararlar (CMK md. 272) 
istinaf yolu ile bölge adliye mahkemelerinde ve sinırl hallerde (CMK md. 286) olmak üzere temyiz yolu ile Yargitay ceza dairelerinde görülmektedir. İlgili Yargıtay ceza dairesi (7. ve 11.) tarafından hükmün bozulması yönünde verilen kararlara karşı bölge adliye mahkemesinin bozmaya uymayarak kararında israr etmesi halinde ise dava dosyası kararlarına uyulması zorunlu olan Yargitay Ceza Genel Kurulunca incelenmekte ve karara bağlanmaktadır.

Adli ve idari yargı uygulamaları arasında farklılık gösteren bir diğer husus ise olağan kanun yollarına başvuru sürelerinde ortaya çıkmaktadır. Şöyle ki idari yargı kapsamında vergi mahkemesi kararının tebliğinden itibaren 30 gün içinde bölge idare mahkemesine istinaf, bölge idare mahkemesinin kararının tebliğinden itibaren 30 gün içinde Danıştay'a temyiz kanun yolu ile başvurulabilmektedir. Adli yargı kapsamında ise asliye ceza mahkemesinin hükmü açıklanmasından itibaren 7 gün içinde bölge adliye mahkemesine istinaf, bölge adliye mahkemesinin hükmü açıklanmasından itibaren 15 gün içinde ise temyiz kanun yolu ile Yargıtay'a başvurulabilmektedir. Ayrıca idari yargı kapsamında yaşanan vergi uyuşmazlıklarında istinaf ve temyiz kanun yollarına gidilmesi durumunda yürütmeyi durdurma talebi bulunulması gerekirken, adli yargı kapsamında yaşanan vergi suçlarına verilen cezalar konusunda yaşanan uyuşmazlıklarda istinaf ve temyiz kanun yollarına gidilmesi durumunda hükmün kesinleşmesi engellenmektedir.

Ayrıca vergi uyuşmazlıkları ile ilgili hem adli, hem idari yargı alanında yaşanan uyuşmazlıkların çözümlerinde zaman zaman Anayasa Mahkemesi görevli olmaktadır. Vergi ve ceza kanunların Anayasa'ya uygunlukları hususunda soyut norm ve somut norm denetiminde Anayasa Mahkemesi görevli olmaktadır. Yine adli ve idari uyuşmazlıklara ilişkin olarak olağan kanun yollarının tüketilmesi durumunda kişilere Anayasa Mahkemesi'ne bireysel başvuru hakkı (Anayasa md.148/3) tanınmış olmakla birlikte, bireysel başvurunun olumsuz sonuçlanması halinde yani iç hukuk yolları tüketildiği takdirde kişilere bu defa AİHM'ne bireysel başvuru hakkı tanınmaktadır. Diğer

\section{Notlar}

${ }^{1}$ http://www.adb.adalet.gov.tr/Sayfalar/istatistikler/istatistikler/ihti yari.pdf (erişim tarihi 27.09.2018)

${ }^{2}$ http://www.adb.adalet.gov.tr/Sayfalar/istatistikler/istatistikler/dav asarti.pdf (erişim tarihi 27.09.2018)

${ }^{3} 2577$ say1lı İdari Yargilama Usulü Kanunu'nun "Vergi Uyuşmazlıklarında Yetki" başlığı altında yer alan 37. madde hükümlerine göre vergi uyuşmazlıklarında yetkili mahkeme vergi mahkemesidir.

Ayrıca 2576 sayılı Bölge İdare Mahkemeleri, İdare Mahkemeleri ve Vergi Mahkemelerinin Kuruluşu ve Görevleri Hakkında Kanun'un "Vergi Mahkemelerinin görevleri" başlı̆g 1 altında yer alan 6. madde hükümlerine göre vergi mahkemeleri:

a) Genel bütçeye, il özel idareleri, belediye ve köylere ait vergi, resim ve harçlar ile benzeri mali yükümler ve bunların zam ve cezaları ile tarifelere ilişkin davaları,

b) (a) bendindeki konularda 6183 sayılı Amme Alacaklarının Tahsil Usulü Hakkında Kanunun uygulanmasına ilişkin davaları,

c) Diğer kanunlarla verilen işleri çözümler.

${ }^{4} 2576$ sayılı Bölge İdare Mahkemeleri, İdare Mahkemeleri ve Vergi Mahkemelerinin Kuruluşu ve Görevleri Hakkında Kanun'un "Bölge idare mahkemelerinin görevleri” başlığı altında yer alan 3/A maddesinin " $b$ " bendi hükmüne göre bölge idare mahkemeleri yargı bir ifadeyle AİHM'ne gidebilmek için Anayasa Mahkemesi'nin karar vermiş olması gerekmektedir.

Öte yandan Uyuşmazlık Mahkemesi de adli ve idari yargı mercileri arasındaki görev ve hüküm uyuşmazlıklarının çözümünde yetkili merci olmaktadır. Dolayısıyla vergi uyuşmazlıklarının çözümünde Uyuşmazlık Mahkemesi de görevli yüksek mahkemelerden birisi olarak kabul edilmektedir.

Anlaşıldığg üzere vergi konusunda vergi dairesi ile ilgili yaşanan uyuşmazlıklarda idari yargı kapsamındaki mahkemeler yetkili olmaktayken vergi suçları neticesinde verilen hürriyeti bağlayıcı cezalarla ilgili yaşanan uyuşmazlıklarda adli yargı kapsamındaki mahkemeler, bazı özellikli durumlarda ise Anayasa Mahkemesi ve Uyuşmazlık Mahkemesi yetkili olmaktadır. Gerek vergi konusunda gerekse de vergi suçları konusunda yaşanan uyuşmazlıklarda takip edilecek olağan kanun yolları (istinaf ve temyiz) benzerlik gösterse de uyuşmazlıkları çözmek amacıyla başvurulacak merciler, başvuru süreleri ve idari yargıdaki yürütmeyi durdurma ile adli yargıdaki hükmün kesinleşmesini engellenme uygulamaları farklılık göstermektedir.

Son olarak vergi uyuşmazlıklarına ilişkin Yargıtay ceza dairelerine $^{18}$ ve Danıştay dava dairelerine ${ }^{19}$ ait 2017 yılı dosya istatistikleri incelendiğinde Danıştay dava dairelerinde sonuçlanan dosya sayısının Yargıtay ceza dairelerinde sonuçlanan dosya sayısının yaklaşık iki katı kadar olduğu anlaşılmaktadır. Ayrıca Danıştay dava dairelerinde bir sonraki yıla devreden dosya sayısının da Yargitay ceza dairelerinde devreden dosya sayısından daha az olduğu anlaşılmaktadır. Çünkü vergi uyuşmazlıklarına ilişkin davalarda Danıştay'da dört farklı daire görev yapmakta iken Yargıtay'da iki farklı daire görev yapmaktadır. Bu nedenle Danıştay’da daha çok sayıda davaya bakılmakta ve bir sonraki yıla daha az sayıda dava dosyası devretmektedir. Söz konusu durumdan hareketle vergi uyuşmazlıklarının çözümlerinde görevli Yargıtay ceza daire sayısının artırılmasının daha fazla dava dosyasının sonuçlandırılmasına neden olacağı öngörülmektedir.

çevresindeki idare ve vergi mahkemeleri arasında çıkan görev ve yetki uyuşmazlıklarını kesin karara bağlamakla görevlidir.

${ }^{5}$ Danıștay, 2575 sayılı Danıștay Kanunu'nun 23/a maddesine göre "İdare Mahkemeleri ile vergi mahkemelerinden verilen kararlar ve ilk derece mahkemesi olarak Danıștay'da görülen davalarla ilgili kararlara karşı temyiz istemlerini inceler ve karara bağlar." 2575 sayılı Danıştay Kanunu'nun 27. maddesine göre "Dava dairelerinden Üçüncü, Dördüncü, Yedinci ve Dokuzuncu daireler vergi dava dairesi ... olarak görev yapar."

${ }^{6} 2018$ y1lı için 36.000 TL'yi aşmayan davaya konu tutarlarda tek hâkim görev almakta, aşan tutarlarda kurul halinde görev alınmaktadır.

${ }^{7}$ İstinaf kanun yolu vergi davalarında ilk derece mahkemeleri olan vergi mahkemeleri ile temyiz incelemelerinde görevli Danıştay arasında ikinci bir denetim mekanizması olarak 28.06.2014 tarih ve 29044 sayılı Resmi Gazete'de yayınlanan Türk Ceza Kanunu İle Bazı Kanunlarda Değişiklik Yapılmasına Dair Kanun (Kanun no: 6545) ile düzenlenmiştir. Ancak istinaf mahkemeleri olarak belirlenen bölge idare mahkemelerinin kuruluşları ve faaliyete geçmeleri 20.07.2016 tarihinde gerçekleşmiş, istinaf kanun yolunun idari yargı alanında faaliyet göstermeye başlamasıyla ülkemizde üç kademeli yargılama sistemine geçilmiştir. 19.09.2018 tarihi itibariyle ülkemizde Anakara, Erzurum, Gaziantep, İstanbul, 
İzmir, Konya ve Samsun illerinde olmak üzere toplam 7 tane bölge idare mahkemeleri faaliyet göstermektedir.

82577 say1lı kanunun 1 inci ek maddesine göre parasal sınırlar; her takvim yılı başından geçerli olmak üzere, önceki yılda uygulanan parasal sınırların, o yıl için Maliye Bakanlığınca her yıl tespit ve ilan edilen yeniden değerleme oranında artırılması suretiyle uygulanmaktadır.

${ }^{9}$ Anayasa Mahkemesi'nin 8.5.2014 tarihli kararına konu olan davada başvurucu, hakkında hesaplanan katma değer vergisi (KDV) ve vergi ziyaı cezasına ilişkin açtığı davanın reddedildiğini, bu nedenle Anayasa'nın 10., 36. ve 73. maddelerinde tanımlanan haklarının ihlal edildiğini ileri sürerek, ihlalin tespitiyle vergi ziyaı cezalı KDV tarhiyatı nedeniyle uğradığı maddi zararın tazminine karar verilmesini talep etmiştir. Anayasa Mahkemesi dava dosyasını incelemiş ve başvurucunun adil yargılanma hakkının ihlal edildiği yönündeki iddialarının "açıkça dayanaktan yoksun olması" nedeniyle kabul edilemez olduğuna, güvence altına alınan makul sürede yargılanma hakkının ihlal edildiği yönündeki iddiasının kabul edilebilir olduğuna ve makul sürede yargılanma hakkının ihlal edildiğine karar vermiştir. Akabinde mahkeme başvurucunun, tarh edilen KDV ve vergi ziyaı cezasından dolayı uğradığını ileri sürdüğü maddi zararının tazmini talebinin reddine ve başvurucu tarafindan yapılan yargılama giderinin başvurucuya ödenmesine karar vermiștir.

${ }^{10}$ İtiraz kanun yolu adli yarg1 kapsamında günümüzde halen uygulanmakta olmasına rağmen, idari yargıdaki itiraz kanun yolu 28.06.2014 tarih ve 29044 sayll Resmi Gazete'de yayınlanarak yürürlüğe giren 6545 sayılı Türk Ceza Kanunu ile Bazı Kanunlarda Değişiklik Yapılmasına Dair Kanun ile kaldırılmıştır.

${ }^{11} \mathrm{CMK}$ 272/3 maddesi gereğince; a) Hapis cezasından çevrilen adlî para cezaları hariç olmak üzere, sonuç olarak belirlenen üç bin Türk Lirası dâhil adlî para cezasına mahkûmiyet hükümlerine, b) Üst sınırı beş yüz günü geçmeyen adlî para cezasını gerektiren suçlardan beraat hükümlerine, c) Kanunlarda kesin olduğu yazılı bulunan hükümlere, karşı istinaf yoluna başvurulamaz.

${ }^{12}$ Bölge adliye mahkemelerinin 07.10.2004 tarih ve 25606 say1l Resmi Gazete'de yayımlanan Adlî Yargı İlk Derece Mahkemeleri İle Bölge Adliye Mahkemelerinin Kuruluş, Görev ve Yetkileri Hakkında Kanun (Kanun no: 5235) ile kurulmaları öngörülmüştür. Ancak bölge adliye mahkemelerinin kuruluşlarını tamamlayarak faaliyete geçmeleri 20.07.2016 tarihinde gerçekleșmiștir. 19.09.2018 tarihi itibariyle ülkemizde Adana, Ankara, Antalya, Bursa, Erzurum, Gaziantep, İstanbul, İzmir, Konya, Sakarya ve Samsun illerinde olmak üzere toplam 11 tane bölge adliye mahkemesi görev yapmaktadır.

${ }^{13}$ Yargitay 11. Ceza Dairesi 2018/4454 Esas ve 2018/6426 sayılı kararında Vergi Usul Kanununa Muhalefet suçu kapsamında Sanığın Torbalı 2. Asliye Ceza Mahkemesi'nce verilen 24.11.2017 tarih ve 2017/189 E., 2017/555 K. sayılı istinaf isteminin süre yönünden reddine dair ek kararına yönelik istinaf başvurusu üzerine İzmir Bölge Adliye Mahkemesi 6. Ceza Dairesi tarafindan verilen 27.12.2017 tarih ve 2017/2903-2245 E-K. sayıl1 kararın kesin nitelikte olduğu anlaşıldığından, dosyanın mahalline iadesi için Yargıtay Cumhuriyet Başsavcılığına TEVDIIINE, 10.07.2018 gününde oybirliği ile karar vermiștir.

${ }^{14}$ Yargitay 11. Ceza Dairesi 2018/3496 Esas ve 2018/5266 say1l kararında Vergi Usul Kanununa Muhalefet suçu kapsamında 5271 sayılı CMK'nın 286/2-a maddesi uyarınca, ilk derece mahkemelerinden verilen beş yıl veya daha az hapis cezaları ile miktarı ne olursa olsun adli para cezalarına ilişkin istinaf başvurusunun esastan reddine dair Bölge Adliye Mahkemesi kararlarının temyizi mümkün olmadığından Ankara Bölge Adliye Mahkemesi 11. Ceza Dairesi'nin sanıklar müdafiinin vaki temyiz isteminin reddine ilişkin 04.01.2018 tarihli ek kararı usul ve yasaya uygun bulunduğundan, sanıklar müdafiinin bu kararın kaldırılmasına dair isteminin 5271 sayılı CMK'nın 296/2 maddesince REDDİNE, 04.06.2018 gününde oybirliği ile karar vermiștir.

${ }^{15}$ Yargitay ceza dairelerinin iş bölümü Yargitay Başkanlar Kurulunun kararı ile her y1l belirlenmektedir. 09/02/2018 tarihli ve
2018/1 sayıl1 Karar ile vergi davalarında 7. ve 11. ceza daireleri görevli olmaktadır.

${ }^{16}$ Anayasa Mahkemesi 2014/120 Esas ve 2015/23 sayılı kararında itiraz yoluna başvuran Ankara 3. Vergi Mahkemesi'nin 4.1.1961 tarihli ve 213 sayıl1 Vergi Usul Kanunu'nun 22.7.1998 tarihli ve 4369 sayılı Kanun'un 11. maddesiyle değiştirilen 344. maddesinin ikinci fikrasında yer alan ".bu fillere iştirak edenlere ise bir kat." ibaresinin Anayasa'nın 2. ve 38. maddelerine aykırılı̆̆ sürülerek iptaline karar verilmesi istemini incelemiş ve söz konusu kanun maddesinde yer alan ifadenin Anayasa'ya aykırı olmadığına ve itirazın REDDINE, 5.3.2015 tarihinde OYBİRLİĞIYYE karar vermiştir.

${ }^{17}$ Uyuşmazlık Mahkemesi 1989/36 Esas nolu kararında VUK'un 359. maddesi uyarınca açılan kamu davasının vergi mahkemesinde değil ceza mahkemesinde görülmesi yönünde karar vermiștir. Açılan kamu davasında Gebze Asliye Ceza Mahkemesi görevli olmasına rağmen, Gebze Asliye Ceza Mahkemesi davanın Kocaeli 1.Vergi Mahkemesinde devam ettiğini belirterek görevsizliğe ve dosyanın Kocaeli 1.Vergi Mahkemesine gönderilmesine karar vermiştir. Kocaeli 1.Vergi Mahkemesi, VUK'un 359. maddesine göre, vergi kaçakçılığı yapan mükellef ve sanıklar hakkında gerekli hapis cezalarının Ceza Mahkemelerince hükmedilmesi ve davanın Gebze Asliye Ceza Mahkemesinde görülmesi gerektiği kanısına vararak Uyuşmazlık Mahkemesine başvurmuştur. Uyuşmazlık Mahkemesi ise inceleme neticesinde idare hukuku alanında görev yapan vergi mahkemelerinde açılan ceza davasının görülmesi mümkün bulunmamasına binaen davanın adli yarg1 yerinde görülmesi ve bu nedenle Gebze Asliye Ceza Mahkemesi'nin görevsizlik kararının kaldırılmasına karar vermiştir.

${ }^{18} \mathrm{https} / / / \mathrm{www} . y a r g i t a y . g o v . t r / d o c u m e n t s /$ istatistikler/2017.pdf (erişim tarihi 23.10.2018)

${ }^{19}$ https://www.danistay.gov.tr/upload/09_04_2018_devreden_gunc el.pdf (erişim tarihi 23.10.2018)

\section{Kaynakça}

Adlî Yarg1 İlk Derece Mahkemeleri ile Bölge Adliye Mahkemelerinin Kuruluş, Görev ve Yetkileri Hakkında Kanun. (2004). T.C. Resmi Gazete, 25606, 7 Ekim 2004.

Ağar, S. (2005). Sahte veya Muhteviyatı İtibariyle Yanıltıc1 Belge Düzenleme veya Kullanma Suçları. Türkiye Barolar Birliği (TBB) Dergisi, 58, 273-301.

Akdemir, T. (2014). Vergi Hukuku Açısından Türk Anayasa Mahkemesi'ne Bireysel Başvuru Yolu, Türkiye Barolar Birliği Dergisi, Say1 111, 255-278.

Akdoğan, A. (2006). Vergi Hukuku ve Türk Vergi Sistemi. Ankara: Gazi Kitabevi.

Altundiş, M. (2007). Vergi Usul Kanununda Yer Alan Vergi Suç ve Cezaları ile Yeni Türk Ceza Kanununun $\mathrm{Bu}$ Suçlara Etkisi. Ankara Barosu Dergisi, 1, 168-179.

Arabuluculuk Daire Başkanlığı (2018a). Dava Şartı Arabuluculuk Uygulama istatistikleri. (Erişim: 27/09/2018),

http://www.adb.adalet.gov.tr/Sayfalar/istatistikler/istatis tikler/davasarti.pdf

Arabuluculuk Daire Başkanlığı, Ihtiyari Arabuluculuk Uygulama Istatistikleri. (Erişim: 27/09/2018), http://www.adb.adalet.gov.tr/Sayfalar/istatistikler/istatis tikler/ihtiyari.pdf 
Aydın, D. (2006). Ceza Muhakemesi Kanununda İtiraz. TBB Dergisi, 65, 61-72.

Bat1, M. (2015), Yeni Bir Yarg1 Yolu Olan İstinaf Mahkemelerinin Tam Kamusal Malların Mahrum Bırakılamaz İlkesini Zedelemesi Sorunsalının Anayasa'nın Hak Arama Hürriyeti Işı̆̆ında Değerlendirilmesi. LEGES Kamu Hukuku Dergisi, 10, 13-33.

Bayraklı, H. H. (2009). Vergi Uyuşmazlıkları ve Çözüm Yolları. Afyonkarahisar: Celepler Matbaacılık.

Bilgin, H. (2009). Anglo Sakson Hukuk Sistemlerinde Arabuluculuk. Hukuk Gündemi Dergisi, 10, 16-24.

Ceza Muhakemesi Kanunu (2004). T.C. Resmi Gazete, 25673, 17 Aralık 2004.

Danıştay Başkanlığı, 2017 Yılı Sonuçlanan ve 2018 Yılına Devreden Dosya İstatistikleri. (Erişim Tarihi: 23.10.2018),

https://www.danistay.gov.tr/upload/09_04_2018_devred en_guncel.pdf

Danıştay Kanunu (1982). T.C. Resmi Gazete, 17580, 20 Ocak 1982.

Ekinci, H., \& Sağlam, M. (2012). 66 Soruda Anayasa Mahkemesine Bireysel Başvuru. Ankara: T.C. Anayasa Mahkemesi Yayını.

Erdoğdu, V. (2013). Vergi Uyuşmazlıklarında Anayasa Mahkemesi'ne Bireysel Başvuru Yolu. ISMMMO Mali Çözüm Dergisi, 117, 99-108.

Hukuk Uyuşmazliklarinda Arabuluculuk Kanunu Yönetmeliği. (2013/mülga). T.C. Resmi Gazete, 28540, 26 Ocak 2013.

Hukuk Uyuşmazliklarinda Arabuluculuk Kanunu Yönetmeliği (2018). T.C. Resmi Gazete, 30439, 2 Haziran 2018.

Hukuk Uyuşmazlıklarında Arabuluculuk Kanunu (2012). T.C. Resmi Gazete, 28331, 22 Haziran 2012.

İdari Yargilama Usulü Kanunu (1982). T.C. Resmi Gazete, 17580, 20 Ocak 1982.

İş Mahkemeleri Kanunu (1950/mülga). T.C. Resmi Gazete, 7424, 4 Şubat 1950.

İş Mahkemeleri Kanunu (2017). T.C. Resmi Gazete, 30221, 25 Ekim 2017.

Karakoç, Y. (2013). Vergi Yargllaması Hukuku, T.C. Anadolu Üniversitesi Yayınları, Yayın No: 2951, Açık Öğretim Fakültesi Yayın No: 1907. Ankara: Saray Matbaacilik.
Kızılot, Ş., \& Kızılot, Z. (2010). Vergi İhtilafları ve Çözüm Yolları. Ankara: Yaklaşım Yayıncılık.

Kızılot, Ş., Şenyüz, D., Taş, M., \& Dönmez, R. (2006). Vergi Hukuku. Ankara: Yaklaşım Yayıncılık.

Korkmaz, R. (2015). Anayasa Mahkemesi'ne Bireysel Başvuruda Uyulması Gereken Süreler. Dokuz Eylül Üniversitesi Hukuk Fakültesi Dergisi, 16 (Özel Sayı), 1951-1986.

Ömercioğlu, A., Dayığlu, M. R., \& Arslan, C. B. (2018). Vergi Suçlarının Türkiye'de Adli Görünümü. Kırıkkale Üniversitesi Sosyal Bilimler Dergisi, 8(1), 51-70.

Öz, E., \& Armağan, A. (2018). Yargı Organları Kararlarına Göre Vergi Kaçakçılığı Suçlarını Önlemede Adli Vergi Cezalarının Rolü. Türkiye Adalet Akademisi Dergisi, 33, $1-38$.

Savaşan, F., Altundemir, M. E., \& Ulupınar, A. (2012). Vergi Uyuşmazlıklarının Çözüm Yollarının Nitel Araştırma Yöntemleriyle Karşılaştırılması. Maliye Dergisi, 162, 126-144.

Şenyüz, D. (2015). Vergi Ceza Hukuku Vergi Kabahatleri ve Suçları. Bursa: Ekin Basım Yayın Dağıtım.

Taşkan, Y. Z. (2007). Vergi Yargılaması Hukukunda Görev ve Yetki. Ankara: Siyasal Kitabevi.

Türk Ceza Kanunu İle Bazi Kanunlarda Değişiklik Yapilmasina Dair Kanun (2014). T.C. Resmi Gazete, 29044, 28 Haziran 2014.

Türk Ceza Kanunu (2004). T.C. Resmi Gazete, 25611, 12 Ekim 2004.

Türkiye Cumhuriyeti Anayasası (1982). T.C. Resmi Gazete, 17863 (Mükerrer), 9 Kasım 1982.

Vergi Usul Kanunu (1961). T.C. Resmi Gazete, 1070310705, 10-12 Ocak 1961.

Yargıtay Başkanlığı, Yargıtay Ceza ve Hukuk Daireleri ile Cumhuriyet Başsavcılığının 2017 Yılına Ait İş Durumunu Gösterir Çizelge. (Erişim Tarihi: 23.10.2018), https://www.yargitay.gov.tr/documents/istatistikler/201 7.pdf

Yüce, M. (2014). Mali Yargllama Hukuku. Bursa: Ekin Basım Yayın Dağıtım.

Yurtyeri, İ., \& Yurtyeri, A. (2012). Vergi Kaçakçılığı Suçunda Soruşturma Usulü ve Yaptırım. Konya Barosu Dergisi, 23, 106-109. 